Terr. Atmos. Ocean. Sci., Vol. 18, No. 2, 223-241, June 2007

\title{
Lithostratigraphy of the Taiwan Chelungpu-Fault Drilling Project-A Borehole and Its Neighboring Region, Central Taiwan
}

\author{
Andrew Tien-Shun Lin ${ }^{1}{ }^{*}$, Shun-Min Wang ${ }^{2}$, Jih-Hao Hung ${ }^{1}$, \\ Ming-Shyan $\mathrm{Wu}^{1,3}$, and Chih-Shae Liu 4
}

(Manuscript received 26 January 2006, in final form 26 December 2006)

\begin{abstract}
A late Miocene to Pleistocene, shallow marine succession of $2003 \mathrm{~m}$ in measured depth was drilled and cored at the TCDP (Taiwan Chelungpufault Drilling Project)-A borehole. We established a lithostratigraphic column for the TCDP-A well and correlated the well-bore rock succession to its surface equivalents and rock successions drilled at nearby oil exploration wells. Our results find that the lithostratigraphy for the TCDP-A borehole is as follows (numbers are in measured depth with reference to wireline logs): (1) 0 - 1013 m: lower Cholan Formation; (2) 1013 - 1300 m: Chinshui Shale; (3) 1300 - 1707 m: Kueichulin Formation; (4) 1707 - 2003 m: Cholan Formation, a repeated formation in the footwall of the Sanyi Fault. Our data show that the Chinshui Shale and Kueichulin Formation are not exposed to the west of the TCDP-A well and the Chi-Chi surface rupture occurs near the base of the Cholan Formation. At TCDP-A borehole the most likely Chi-Chi rupture lies at $\mathbf{1 1 1 1} \mathbf{m}$ in the Chinshui Shale while its surface equivalent occurs near the base of the Cholan Formation, thereby indicating that the Chi-Chi rupture cuts stratigraphic upsection of some 170 meters in the direction of faulting transport.
\end{abstract}

\footnotetext{
${ }^{1}$ Department of Earth Sciences and Institute of Geophysics, National Central University, Chung-Li, Taiwan, ROC

2 Institute of Applied Geology, National Central University, Chung-Li, Taiwan, ROC

${ }^{3}$ CPC Corporation, Taiwan, ROC

4 Taiwan Area National Expressway Engineering Bureau, Taipei, Taiwan, ROC

* Corresponding author address: Prof. Andrew Tien-Shun Lin, Department of Earth Sciences and Institute of Geophysics, National Central University, Chung-Li, Taiwan, ROC; E-mail: andrewl@ncu. edu.tw doi: 10.3319/TAO.2007.18.2.223(TCDP)
} 
Shallow drilling prior to the Chi-Chi earthquake at where later the Chi-Chi rupture had occurred indicates that the Chi-Chi rupture occurs on a pre-existing fault plane. Another shallow borehole located some $240 \mathrm{~m}$ to the west of the Chi-Chi surface rupture encountered a previously unknown thrust fault. The hangingwall material of this fault is intensively weathered in contrast to the fresh hangingwall rocks of the Chi-Chi rupture encountered further east noted above. The extent of weathering in the above two fault zones indicates the thrust fault encountered at the west is older than the currently active Chi-Chi rupture in the east. Noting that the Sanyi fault is previously reported as inactive since late Pleistocene above observations suggest a hinterlandward (i.e., eastward) migration of splay faults within the thrust-sheet bounding fault zone.

\section{(Key words: Taiwan Chelungpu-fault Drilling Project, Core lithofacies, Chi-Chi rupture)}

\section{INTRODUCTION}

The major scientific objective for the Taiwan Chelungpu-fault Drilling Project (TCDP) aims to understand the physical mechanisms involved in the large amount of fault slip during the 1999 Chi-Chi earthquake (e.g., Mori et al. 2002). The drilling recovered continuous core material from 432 to $2003 \mathrm{~m}$. Two fault zones, upper and lower fault zones in the range of $1111 \sim 1241$ and $1519 \sim 1856 \mathrm{~m}$, respectively, were encountered at the TCDP-A drill bore (Hung et al. 2007). Hung et al. (2007) pointed out that the upper fault zone corresponds to the Chelungpu fault and the slip surface at $1111 \mathrm{~m}$ is the most likely slip surface during the Chi-Chi earthquake while the lower fault zone is the Sanyi fault, a thrust-sheet bounding fault which brings the Miocene Kueichulin Formation on top of the Pliocene Cholan Formation. The Chi-Chi rupture, Sanyi fault zone together with part of the equivalent rock successions drilled at the TCDP borehole all expose to the west of the drill site because of the westward thrusting and subsequent erosion of the Sanyi thrust sheet. In this regard, one of the objectives of this paper is to correlate the lithologies and structures encountered at the TCDP-A to the stratigraphy and structural features exposed on the hangingwall of the Sanyi fault system.

There has been controversy on what rock formation that the Chi-Chi surface rupture developed to the west of the TCDP drill site and to the north of the Tali River. Wang et al. (2002), for example, placed the Chi-Chi rupture at the base of the Chinshui Shale according to the geological map of the Chinese Petroleum Corporation (1982). A new geological map (i.e., Ho and Chen 2000) and recent studies (e.g., Chen and Ho 2000) show that Chinshui Shale and older formations do not crop out on the hangingwall of the Sanyi fault, however. In order to determine the rock formations exposed on the Sanyi thrust sheet in and around the Chi-Chi surface rupture, we establish, for the first time, a continuous lithostratigraphic column from a series of shallow drill bores to serve a basis for rock formation determination and stratigraphic correlation in the study area.

To serve the above purposes, we employ various studies on outcrops, cores of TCDP-A, a series of shallow boreholes nearby TCDP-A drill site, and wireline logs of TCDP-A and Chinese 
Petroleum Corporation (CPC) wells. This approach has enabled us to: (1) present a lithostratigraphic column and establish lithostratigraphic units for the TCDP-A borehole; (2) correlate the drilled rocks to their exposed equivalents to the west of the drill site and to equivalent rock successions drilled at nearby CPC wells; (3) examine the geology and shallow subsurface structure in the thrust-sheet bounding fault zone; and (4) reveal the shallow structures near the Chi-Chi surface rupture.

\section{GEOLOGICAL FRAMEWORK}

The TCDP-A borehole locates structurally on the hangingwall of the Sanyi fault and stratigraphically on the lower part of the Pliocene Cholan Formation (Figs. 1a, 2). Here we present a brief summary for the structure and stratigraphy of the study area.

\subsection{Geological Structure}

Figure 1a shows a series of fold-and-thrust sheets in central-western Taiwan. From east to west, the thrust sheet-bounding faults are the Shuantung fault (STF in Fig. 1a, Lo et al. 1999), Chelungpu (CLF) and Sanyi (SYF) faults (Ho and Chen 2000), and Changhua fault (CHF, Ho and Chen 2000). The westward thrusting of the Chelungpu-Sanyi fault system has tilted the hangingwall strata to the east with increasing bedding dips (up to about $50^{\circ}$ ) toward the thrust fault (Fig. 2). To the west of the thrust sheet, lies a thick sequence of flat-lying Quaternary fluvial sandstones/conglomerates, the Toukoshan Formation, that accumulated in the Taichung basin (Chang 1971), a piggyback basin developed on top of the Changhua fault.

The location of the Chi-Chi rupture relative to the mountain front in the study area changes across the Tali River (Fig. 2). To the south of the Tali River (termed hereafter "southern part"), the surface rupture develops in the Chinshui Shale and along the junction between the mountain front and Taichung basin (Huang et al. 2000). By contrast, to the north of the Tali River (termed hereafter "northern part"), the Chi-Chi surface rupture does not run along the mountain front. Instead, it occurs a couple of hundred meters to the east of the mountain front at where no active faults had been previously reported. Chen et al. (2003) coined this part of rupture the Shihkang fault.

The reason why the northern part runs inside the mountain front instead of running along the leading edge of mountain front as the southern part does was not clear. Ho and Chen (2000) shows that a left-lateral tear fault, trending in the east-southeast direction, may exist at the Tali River (Fig. 2). We recognized a NWW-striking left-lateral fault at some $300 \mathrm{~m}$ upstream to the Chi-Chi rupture on the Tali River bed. We interpreted this fault as one of the branch faults in the tear fault zone. This tear fault offsets the strata to the left and brings the older Chinshui Shale in the south into contact with the younger Cholan Formation (see below) in the north. The faulting may have also offset the mountain front to the left. It is therefore likely that, during the Chi-Chi earthquake rupture process, the rupture propagated from the hypocenter in the south and ran along the leading edge of the mountain front. Upon cutting through the preexisting left-lateral tear fault near the Tali River, the rupture went straight into the mountain front in the north and cut into strata younger than the Chinshui Shale. 


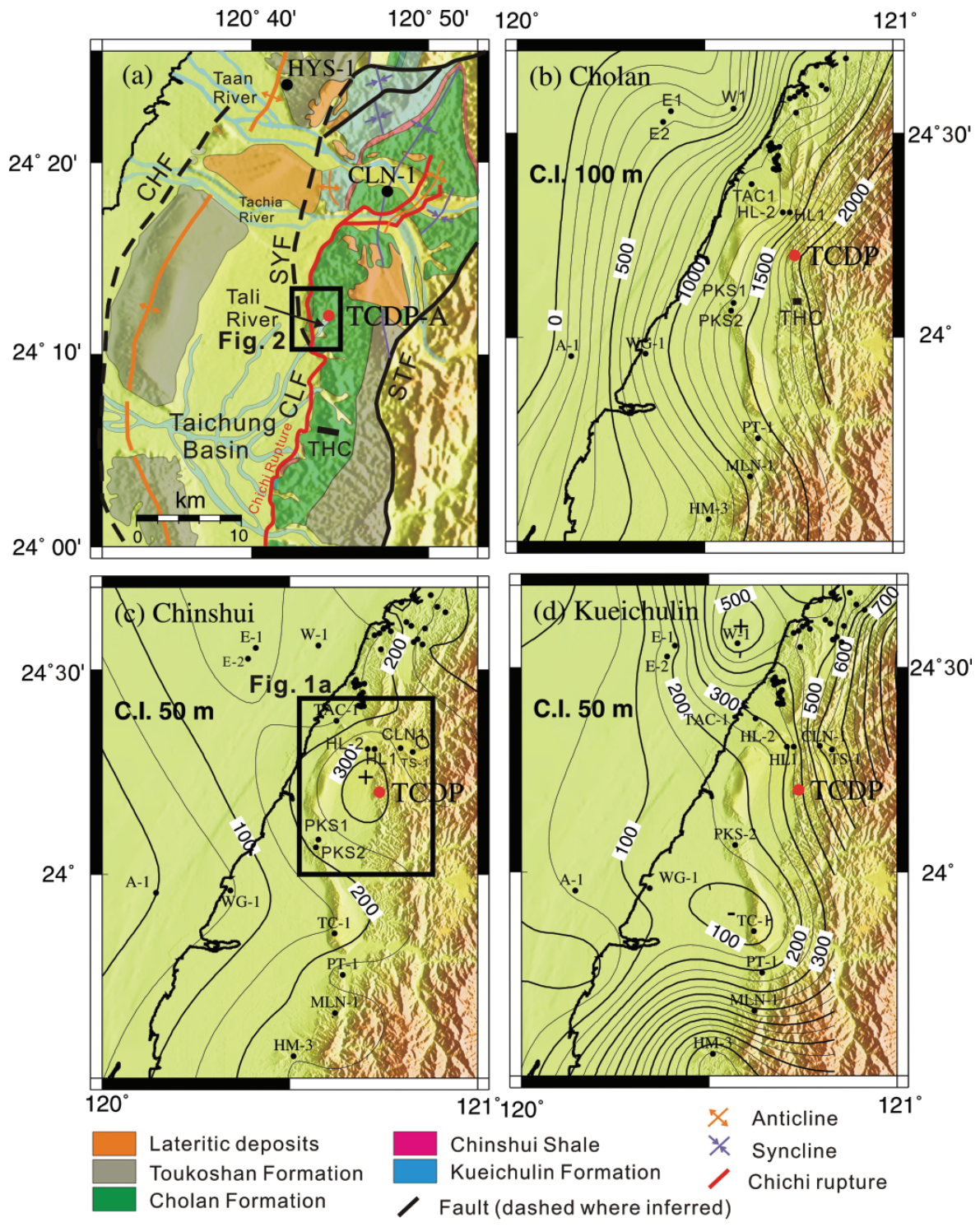

Fig. 1. Maps of central-western Taiwan showing the stratigraphy and geological structures (a) as well as sediment isopachs of the Cholan Formation (b), Chinshui Shale (c), and Kueichulin Formation (d). The stratigraphic thicknesses (unit in meter) are from exploration wells drilled by the Chinese Petroleum Corporation. The area shown in (a) is outlined by a rectangle shown in (c) and the small rectangle in (a) is shown in Fig. 2. Stratigraphic correlation among wells of HYS-1, CLN-1, TCDP-A, and THC (Tsaohu River section) is shown in Fig. 4. CHF: Changhua fault, CLF: Chelungpu fault, STF: Shuantung fault, SYF: Sanyi fault. 


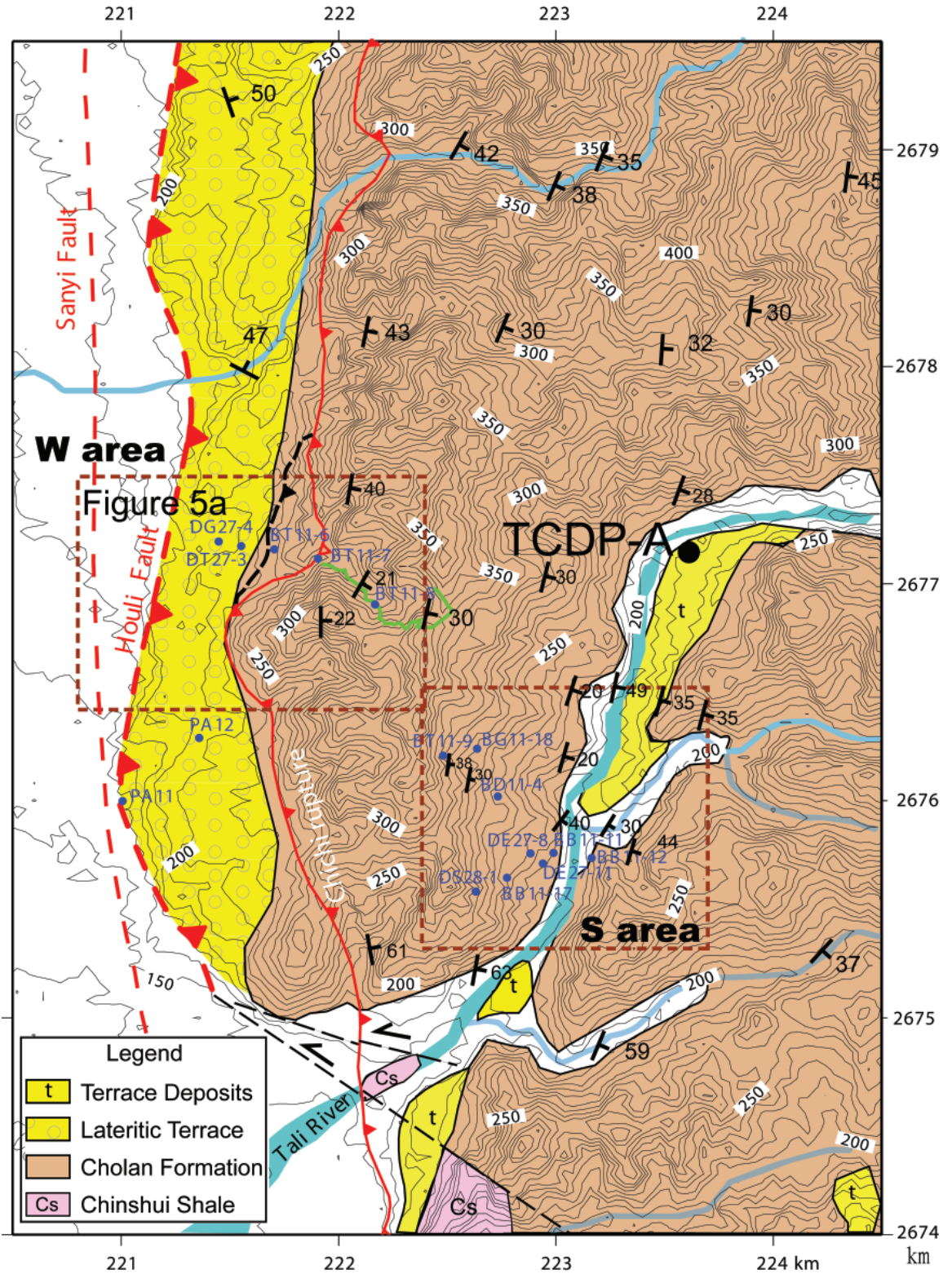

Fig. 2. Geological map of the study area (modified from Ho and Chen 2000). The locations for the Sanyi and Houli faults are from Chen et al. (2003). The surface stratigraphic column shown in Fig. 3a is constructed using shallow boreholes (blue dots) and the Fongdonshi trail (green line). Figure 5a shows the detail of the $\mathrm{W}$ area. Note that a left-lateral strikeslip fault near the Tali River offsets the Cholan Formation to the left across the fault. 


\subsection{Stratigraphy}

The Chelungpu-Sanyi thrust sheet consists of a series of rock formations; they are, from the oldest to the youngest, the Kueichulin Formation (late Miocene to early Pliocene), Chinshui Shale (late Pliocene), Cholan Formation (late Pliocene to early Pleistocene), and Toukoshan Formation (late early to late Pleistocene). This sedimentary succession amounts to about $4500 \mathrm{~m}$ thick and accumulated in the Taiwan foreland basin (Chen et al 2001; Lin et al. 2003). It consists of two tectono-stratigraphic cycles: a transgressive cycle (Kueichulin Formation and Chinshui Shale) that deepens from inner shelf to outer shelf environments followed by a regressive cycle (Cholan and Toukoshan formations) that shoals from inner shelf to braided river settings.

The TCDP drill site locates stratigraphically at the lower part of the Cholan Formation (Fig. 2). The drilling encountered three formations: Cholan Formation (lower part), Chinshui Shale and Kueichulin Formation (upper part). Figures $1 \mathrm{~b}$ to d show the maps of sediment isopachs for these three formations in west-central Taiwan. Formation thicknesses are drawn from CPC exploration wells along with one outcrop section at the Tsaohu River (THC in Fig. 1b, Chen et al. 2001) for the Cholan Formation thickness. The formation thicknesses were gridded at 1 arc-minute interval using a minimum curvature algorithm (Smith and Wessel 1990) and assuming linear interpolation between data points. Figures $1 \mathrm{~b}$ to $\mathrm{d}$ show that sediment thickness of these three formations thickens toward the east and the general strike of contours follows the strike of mountain belts in the NNE direction, reflecting the increase of foreland subsidence toward the orogenic belts. From the sediment isopachs, the predicted formation thicknesses at TCDP drill site are: Cholan Formation - 1909 m, Chinshui Shale - 308 m, and Kueichulin Formation - 380 m, respectively.

\section{LITHOSTRATIGRAPHY}

In order to determine the lithostratigraphic units penetrated at TCDP-A borehole, we first established a lithostratigraphic column as shown in Fig. 3 by examining cores and cuttings retrieved from the borehole. The borehole rock succession was then correlated to the lithostratigraphic column established from outcrops and shallow boreholes located to the west of the TCDP-A drill site (Fig. 3). This practice enables us in recognizing surface rock equivalents to the rocks drilled at TCDP-A. The rock succession at TCDP-A was further correlated to nearby oil exploration wells as well as the lithostratigraphic units exposed along the Tsaohu River (Fig. 4). These approaches help to establish a robust lithostratigraphic framework constrained both by surface and subsurface geology. This section describes the results from approaches noted above.

\subsection{TCDP-A Borehole}

The TCDP-A borehole $\left(120.73916^{\circ} \mathrm{E}, 24.20083^{\circ} \mathrm{N}\right)$ was spud in at $205 \mathrm{~m}$ ground level with derrick floor $3 \mathrm{~m}$ above ground level. The hole reached a total depth of $2003 \mathrm{~m}$ (all depths are given below derrick floor with reference to wireline logs). Ditch cuttings for every $10 \mathrm{~m}$ 
were collected from $0 \sim 432 \mathrm{~m}$ and cores of $83 \mathrm{~mm}$ in diameter were retrieved from $432 \sim 2003 \mathrm{~m}$ with 790 core runs and an average core recovery of $92 \%$. Figure 3 shows the stratigraphic column, gamma-ray log, and frequency of fracture occurrence for the TCDP-A borehole. Figure 3a also shows the lithologic correlation between this borehole and its surface equivalents. The depth scale is referenced to gamma-ray log. By contrast, the length of drill strings was used to calculate the depth at which cores were recovered. There is therefore a slight depth difference between log and core depths for the same stratigraphic horizons. The loss of cores further complicated this situation.

The TCDP-A well bore is slightly deviated from vertical above 1600 meters (less than $4^{\circ}$ ) but gradually increases its vertical deviation below $1600 \mathrm{~m}$, for example, $11^{\circ}$ at $1885 \mathrm{~m}$. Deviation angle below $1885 \mathrm{~m}$ to the total depth at $2003 \mathrm{~m}$ was not measured but is believed to be greater than 11 degrees. The bed dip measured from cores is around $30^{\circ}$ above $1850 \mathrm{~m}$. From 1850 to $2003 \mathrm{~m}$ bed dip is around $70^{\circ}$ in average. The bed dip above $1850 \mathrm{~m}$ (i.e., $30^{\circ}$ ) is consistent with outcrop exposures near the drill site, which show bedding attitudes in the range of $\mathrm{N} 5 \sim 15^{\circ} \mathrm{E}, 28 \sim 35^{\circ} \mathrm{SE}$ (recorded in quadrant method). The increase of well-bore deviation and bed dip below 1600 and 1850 m, respectively, coincides with the Sanyi fault zone in the interval of $1519 \sim 1856 \mathrm{~m}$ (Hung et al. 2007).

The depth given in Fig. 3 was measured along the borehole with reference to wireline logs and hence it is measured depth (MD). Because the strata are tilted the measured depth yields apparent stratigraphic thickness. For (nearly) vertical borehole (i.e., above $1600 \mathrm{~m}$ ), the true stratigraphic thickness (TST) is equal to measured thickness times $\cos (\theta)$, where $\theta$ is the true bed dip measured from cores. Therefore, the TST above $1600 \mathrm{~m}$ is around $87 \%$ of the measured thickness shown in Fig. 3.

The following paragraphs give the detail of the lithostratigraphy of the borehole by examining the rock types (texture and structures) and stratigraphic contacts. From the oldest to the youngest formations they were described below.

\subsubsection{Kueichulin Formation (Yutengping Sandstone Member) Interval: 1300 - 1707 m Dominant Lithology: Muddy Sandstone}

The Kueichulin Formation consists primarily of sandstone and bioturbated clayey siltstone. The penetrated Kueichulin Formation is faulted at its base at $1707 \mathrm{~m}$, interpreted as the main slip surface of the Sanyi fault zone (e.g., Hung et al. 2007). The drilled interval is equivalent to the Yutengping Sandstone Member of the Kueichulin Formation according to lithostratigraphic correlation among nearby boreholes (Fig. 4). For this interval, there is an overall upward increase in clay content and an upward decrease in grain size. The lower part $(1707 \sim 1600 \mathrm{~m})$ is comprised mainly of medium to very thickly bedded, light gray, fine-grained, well-sorted sandstone with evenly dispersed fine-grained carbonaceous matters. The lower part contains minor amount of bioturbated siltstone and no claystone. A few thinly-bedded fossil horizons are present. The upper part of the Yutengping Sandstone Member (1600 $1300 \mathrm{~m})$ comprises primarily muddy sandstones with a few clean sandstone beds and claystone strata. All the above units exhibit bioturbated features. 
(a)
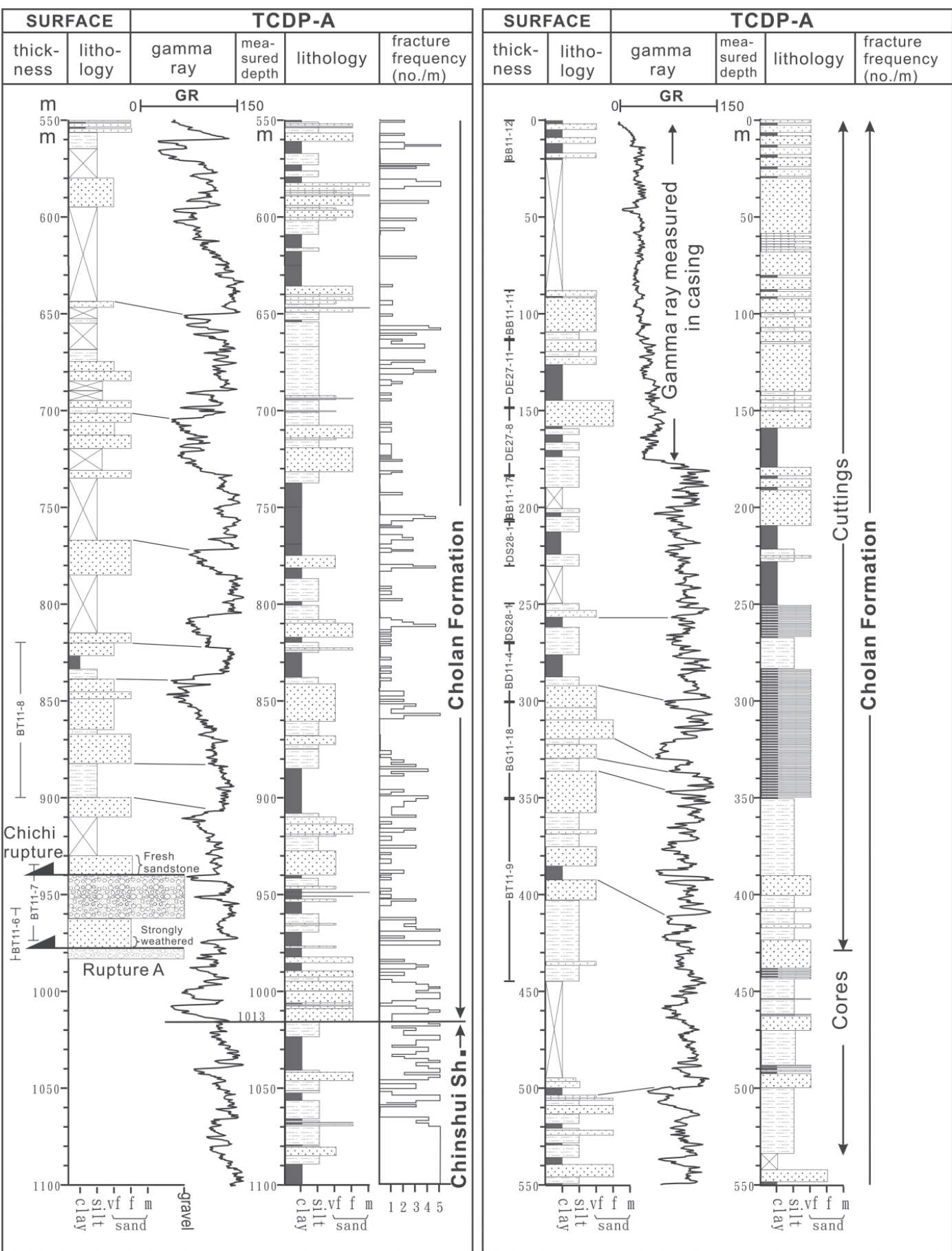
(b)

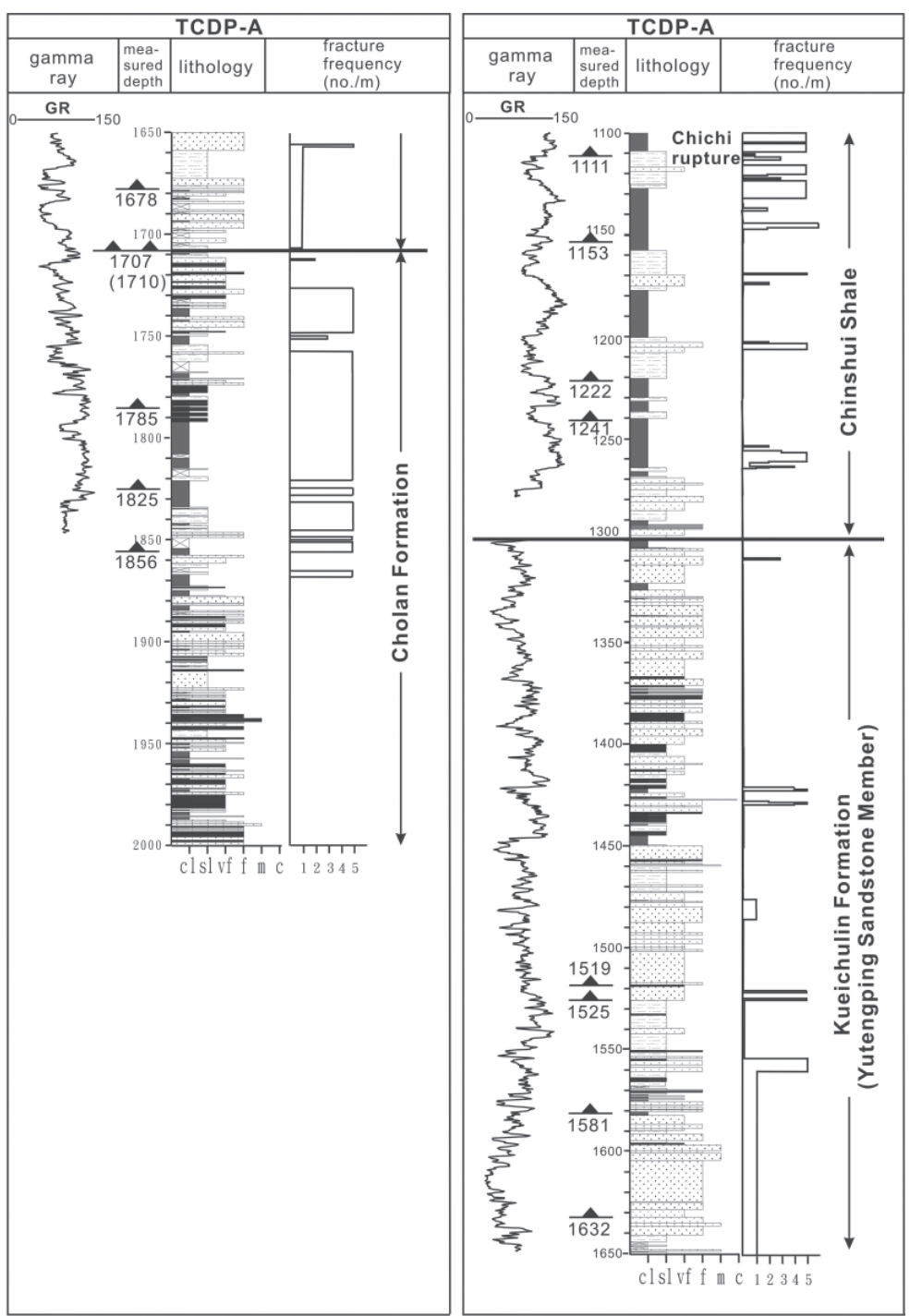

Fig. 3. Lithology, lithostratigraphy, and gamma-ray curve of the TCDP-A borehole ( $a$ and $b$ ) as well as the stratigraphic column (a) constructed from shallow boreholes. Borehole names are given to the left alongside the thickness scale (see Fig. 2 for borehole locations). Solid lines between the TCDP-A and surface rock column show the lithological correlations. The frequency of fracture occurrence in the TCDP cores is shown as numbers of fractures per meter (no. $\mathrm{m}^{-1}$ ) at the right alongside the lithological column. Fault zones reported in Hung et al. (2007) are shown in (b). Note that the surface Chi-Chi rupture occurs near the base of the Cholan Formation (a) while the Chi-Chi rupture was encountered at $1111 \mathrm{~m}$ at TCDP-A (b). 


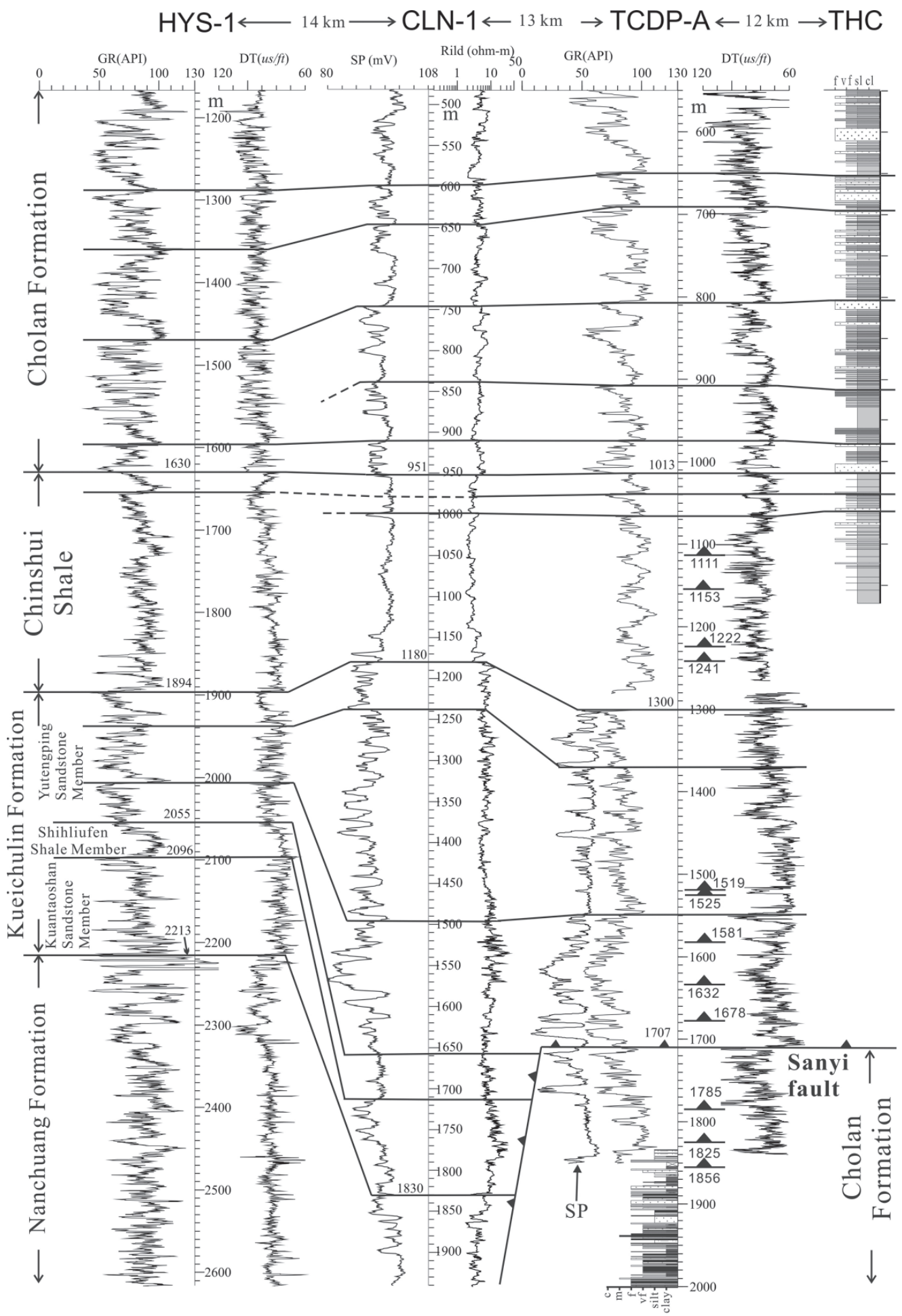


The Kueichulin Formation or the Yutengping Sandstone Member drilled at TCDP-A is distinguished from the Cholan Formation (discussed later) by the absence of thick $(>5 \mathrm{~m})$ claystone intervals. The stratigraphic thickness of the Kueichulin Formation near the TCDP drill site is estimated to be around $400 \mathrm{~m}$ (Fig. 1d) derived from sediment isopachs. The drilled (measured) thickness at the TCDP-A borehole is $407 \mathrm{~m}$ (Figs. 3, 4) for this formation (i.e., Yutengping Sandstone Member) and its true thickness is $353 \mathrm{~m}$, taking into account the bedding dip of 30 degrees. The above thickness (i.e., $353 \mathrm{~m}$ ) is not the true formation thickness of the Yutengping Sandstone Member, however, as it has been strongly sheared and is truncated at its base by the Sanyi fault. The Yutengping Sandstone Member was also partly recovered ( $220 \mathrm{~m}$ in thickness) by a recent shallow drilling at BH-1A well near Fengyuan (Huang et al. 2002), which is about $7 \mathrm{~km}$ to the north of the TCDP drill site.

\subsubsection{Chinshui Shale \\ Interval: 1013 - $1300 \mathrm{~m}$ \\ Dominant Lithologies: Claystones and Siltstones}

The Chinshui Shale is dominated by claystone with subordinate amounts of siltstones and muddy sandstones. There are six claystone intervals. Each interval ranges in thickness from 5 to $20 \mathrm{~m}$ and is characterized by massive claystone with scattered forams, gastropods, and bivalves. The claystone beds usually coarsen upward into siltstones with strongly- to moderately-bioturbated texture. A few coarsening-upward successions may be capped by up to 5 -meter thick muddy sandstones. The characteristic features for the Chinshui Shale are a few tens of meter-thick claystone beds and the absence of greater than 5-meter thick sandstone beds.

Figure 1c shows that the predicted thickness for this unit at the TCDP drill site is about $308 \mathrm{~m}$ interpolated from nearby well/outcrop data shown in Fig. 1c. The true stratigraphic thickness for this unit drilled at the TCDP-A borehole is $249 \mathrm{~m}$ (Fig. 3), which is $59 \mathrm{~m}$ less than the prediction. The thickness difference maybe due to the effect of faulting within the Chinshui Shale as Hung et al. (2007) reported four fault zones in this formation. There is also a possibility that the estimated thickness, $308 \mathrm{~m}$, is an overestimate resulting from the interpolation processes.

Fig. 4. Stratigraphic correlation among boreholes of HYS-1, CLN-1, and TCDP-A together with the Tsaohu River (THC, from Chen et al. 2001) section (see Fig. 1a for locations). Solid lines show correlatable stratigraphic surfaces among rock columns, dashed where inferred. At the TCDP-A well there is a sharp offset of the sonic (DT) log across $1707 \mathrm{~m}$ depth, which is interpreted as the main slip surface of the Sanyi fault. The interval of $1707 \sim 2003 \mathrm{~m}$ is the Cholan Formation. Fault zones (i.e., 1111 $1856 \mathrm{~m}$ ) reported in Hung et al. (2007) are shown at the TCDP-A column. 


\subsubsection{Cholan Formation \\ Intervals: 0 - 1013 and $1707-2003 \mathrm{~m}$ \\ Dominant Lithologies: Sandstone, Siltstone, Claystone}

The Cholan Formation is encountered at two intervals, 0 - $1013 \mathrm{~m}$ and $1707-2003 \mathrm{~m}$, respectively. The $0-1013 \mathrm{~m}$ interval is equivalent to the lower part of this formation exposed some $10 \mathrm{~km}$ south of the drill site along the Tsaohu River. A lithostratigraphic column established along this river is reported by Chen et al. (2001) and is incorporated in Fig. 4. This stratigraphic column is correlated to the TCDP-A drilled section as well as to nearby oil wells (Fig. 4). The Cholan Formation consists of a series of coarsening-upward successions. Each succession is characterized by claystones at its base that grade upward into siltstone and very thick sandstone beds at its top, totaling up to $70 \mathrm{~m}$ in measured thickness. The prominent feature for the Cholan Formation is the presence of these very thick and cyclic successions characterized by up to $10 \mathrm{~m}$ thick claystones at their bases and very thick, non-bioturbated sandstones at their tops, a feature that can be used to distinguish this formation from the Chinshui Shale and Kueichulin Formation.

There is a sharp break in log responses at $1707 \mathrm{~m}$ and the lithology changes from indurated and bioturbated sandstones above to loose and mostly non-bioturbated sandstone with very thick claystone below. There is an in-situ ostrea horizon encased in thick mudstone at 1754 m, a characteristic feature for the middle and upper Cholan Formation. Nannofossil biostratigraphy of this borehole (Wu et al. 2007) shows the 1707 - 2003-m interval is of NN16 18 biozones, equivalent to the Cholan Formation. This unit is truncated by a thrust fault at its top at $1707 \mathrm{~m}$, interpreted as the main slip surface of the Sanyi thrust (Hung et al. 2007).

The Cholan Formation at the footwall immediately to the west of the Sanyi thrust was also drilled at the HL-2 well to the north of the Tachia River (Fig. 1). At the HL-2 well, the top of the Cholan Formation is at $1864 \mathrm{~m}$, a depth comparable to the drilled depth of the Cholan Formation in the footwall of the Sanyi thrust at TCDP-A.

\subsection{Outcrops and Shallow Boreholes}

We utilized 13 shallow boreholes $(20 \sim 100 \mathrm{~m}$ in drill depth) together with an outcrop section to establish a stratigraphic column to the west of the TCDP-A drill site as shown in Fig. 3. The measured formation thickness at outcrops and shallow boreholes is converted to thickness (or depth) of $30^{\circ}$-dipping strata as if measured along a vertical borehole, a situation similar to that of TCDP-A. This practice places the vertical scale in the same fashion for the stratigraphic columnar sections established both at TCDP-A borehole and outcrop/shallow boreholes.

For the purpose of constructing a freeway to the west of the TCDP-A drill site, up to 60 shallow boreholes were drilled during 1997 - 1999 by the Taiwan Area National Expressway Engineering Bureau. Among these boreholes, we selected an array of 13 boreholes arranged in an east to west orientation for constructing a stratigraphic column. Figure 2 shows the employed borehole locations, which can be grouped into two areas (i.e., $\mathrm{S}$ and $\mathrm{W}$ areas). Names of the employed borehole are labeled alongside the stratigraphic column shown in Fig. 3a. For constructing a stratigraphic section from these boreholes we started by preparing topographic 
maps of $1 / 2500$ scale with 5-m contour interval as well as two topographic profiles normal to the strike of the strata in the $\mathrm{S}$ and $\mathrm{W}$ areas, respectively. The lithology and thickness of the strata penetrated at boreholes were projected onto the topographic profiles taking into account the effect of topography. We then measured the stratigraphic thickness from these two topographic profiles and plotted the lithologies along the stratigraphic column. In the $\mathrm{W}$ area, a stratigraphic column from the Fongdonshi trail (the green line in Fig. 2) helps to infill the stratigraphic column where strata are not penetrated by shallow drilling. This part of the road $\log$ is represented by the interval of $445-820 \mathrm{~m}$ shown in Fig. 3a.

In the $\mathrm{W}$ area (Fig. 2), BT11-7 borehole penetrated the pre-existing Chi-Chi rupture and BT11-6 encountered an older fault (see later). We placed their stratigraphic positions as shown in Fig. 3a according to the surface geology. We see from Fig. 3 that the above two fault zones were developed at sand-prone intervals.

Figure 3a shows that lithologies at outcrops and shallow drill bores are predominantly very thick sandstones and siltstones. There are a few thick covered intervals because of vegetation, however. These covered intervals may be of shale in lithology, as shale is prone for weathering and vegetation. There is indeed a good correlation between the covered intervals and the thick shale intervals drilled at TCDP-A as shown in Fig. 3a. Lithology of TCDP-A exhibits a few thick (up to $50 \mathrm{~m}$ ) shale intervals in the lower part of the Cholan Formation (Fig. 3a). The surface equivalents for those thick shale intervals of the Cholan Formation may be mistaken for being the Chinshui Shale. The stratigraphic column established from outcrops and shallow drilling results further indicate that individual sandstone beds commonly exceeds 10 or $20 \mathrm{~m}$ in thickness in the $\mathrm{W}$ area and along the Fongdonshi trail (the green line in Fig. 2) of the lower Cholan Formation. By contrast, the sandstone bed of Chinshui Shale encountered at the nearby TCDP-A borehole never exceeds $5 \mathrm{~m}$. In addition, the average bedding dip (i.e., $30^{\circ}$ ) of the rock exposures to the west of the drill site is similar to their subsurface equivalents measured at TCDP borehole. Using this geometric relationship and taking into account the effect of topography, the base of the Cholan Formation drilled at TCDP-A (i.e., at $1013 \mathrm{~m}$, Fig. 3a) can be projected onto the topography. This practice places the base of the Cholan Formation near the line of the Chi-Chi rupture, suggesting the rock sequence exposed along the Fongdonshi trail still belongs to the Cholan Formation. Examinations of outcrops exposed to the west of the Chi-Chi rupture and shallow boreholes (e.g., BT-11-6 and BT-11-7 shown in Figs. 2 and 3a) in the $\mathrm{W}$ area indicate that thick sandstone is the dominant lithology. All above lines of evidence suggest that the rock sequence that hosts the Chi-Chi rupture is the Cholan Formation, a view similar to the conclusion of Ho and Chen (2000).

By contrast, the geological map of the Chinese Petroleum Corporation (1982) depicts the Chinshui Shale to the west of TCDP-A borehole as about $400 \mathrm{~m}$ in map-width and its upper boundary is near the BT-11-8 shallow borehole (Fig. 2), corresponding to about $850 \mathrm{~m}$ of the stratigraphic column shown in Fig. 3a. The lower boundary of the Chinshui Shale of the Chinese Petroleum Corporation (1982) is near the junction between the mountain front and terrace and beneath the terrace. Our stratigraphic data (Fig. 3a) indicate the above region for the so-called Chinshui Shale shown in the Chinese Petroleum Corporation (1982) are of dominant sandstone lithology rather than shale and this finding negates the occurrence of the Chinshui Shale to the west of the TCDP drill site. 
Hung et al. (2007) has recognized that $1111 \mathrm{~m}$ in the Chinshui Shale is the Chi-Chi rupture surface at the TCDP-A borehole. Lithological correlation between surface rocks and TCDP-A cores (Fig. 3a) reveals that the surface Chi-Chi rupture occurs near the base of the Cholan Formation, however. It therefore suggests that the Chi-Chi rupture is not a bedding-parallel thrust, but it cuts stratigraphic upsection of some 170 meters in the direction of faulting transport.

\subsection{Regional Lithological Correlation}

We attempted to frame the TCDP-A stratigraphy and its surface equivalent to a regional context. By doing so, we correlated the TCDP-A stratigraphy to nearby oil-exploration wells and an outcrop section along the Tsaohu River, which is documented in Chen et al. (2001). Figure 4 shows that there are four types of wireline logs as lithology indicators used for correlation: (1) gamma-ray radiation (GR, unit in API): the larger the value the more the content of uranium, thorium, and potassium-bearing minerals (usually clay minerals). GR log is therefore used as a shaly-index log. Taking the GR log of TCDP-A as an example (Fig. 3), for GR value greater than 105 API it indicates claystone; for GR value less than 75 API it indicates clean sandstone; for GR value lying in between 75 and 105 API it represents muddy sandstone or siltstone. The above GR values and corresponding lithology are confirmed by core examinations; (2) Spontaneous potential (SP, unit in millivolts, $\mathrm{mV}$ ): The SP log is a record of direct current voltage (or potential) that develops naturally between a moveable electrode in the well bore and a fixed electrode located at the surface. SP log is often used as a permeable-zone and shaliness indicators. Figure 4 shows that when SP log swings to the left it indicates permeable zones and sand-dominated lithology; (3) P-wave interval transit time (DT, unit in $\mu s f t^{-1}$ ): For non-calcareous strata, claystone has lower interval transit time (i.e., higher velocity) and sandstone shows higher interval transit time (i.e., lower velocity). For the Taiwan Cenozoic siliciclastic sediments, interval transit time decreases in increasing sediment burial depth, reflecting predominantly the effect of mechanical compaction of sediments (Lin et al. 2003); (4) Resistivity (Rild, unit in Ohm-m): Rock resistivity measured by induction method (Rild). Sandstone has higher resistivity and claystone shows lower resistivity.

In addition to the above lithology indicators, the lithology at CPC boreholes were further confirmed by ditch-cutting examinations documented in each well completion report. There is a good lithological correlation among the stratigraphic columns shown in Fig. 4. The Cholan Formation shows cyclic successions of a sand-dominated series with thick mudstone at many intervals, a characteristic feature also seen at TCDP cores. At the base of the Cholan Formation it is a fining-upward succession at all the correlated stratigraphic columns, including the one along the Tsaohu River (THC in Fig. 4). At many intervals the GR values for the Cholan Formation are less than 75 API, indicating clean-sand intervals (e.g., HYS-1 and TCDP-A boreholes). Equivalent clean-sand intervals at CLN-1 well show left-deflection of the SP curve, suggesting permeable zones correlatable to clean sandstones at adjacent wells.

The Chinshui Shale is a mud-dominated sequence with a few muddy sandstone or siltstone intervals and no thick clean sandstone beds as shown on the log curves (Fig. 4). The GR values for the Chinshui Shale mainly range from 75 to 105 API. The base of the Chinshui Shale is not a sharp boundary but it is marked by a transition from thick sandstones in the 
lower part to claystone to siltstones/sandstones at the upper part. This feature is best seen at CLN-1 well. There are four bedding-parallel thrust-fault zones (i.e., 1111, 1153, 1222, $1241 \mathrm{~m}$ ) in the Chinshui Shale at TCDP-A according to Hung et al. (2007), while the Chinshui Shale at HYS-1 and CLN-1 wells represent un-faulted sections.

Figure 4 shows that the Kueichulin Formation is a sand-prone formation with GR values largely less than 75 API, indicating sandstones. The Kueichulin Formation at HYS-1 and CLN-1 wells is un-faulted and exhibits three members of Kuantaoshan Sandstone, Shihliufen Shale, and Yutengping Sandstone, from the oldest to the youngest, respectively. The Shihliufen Shale Member is about 50-meter-thick shale, which is not found at TCDP-A. At TCDP-A well there is a significant lithology change across $1707 \mathrm{~m}$ as noted in preceding paragraphs. $1707 \mathrm{~m}$ is interpreted as the Sanyi thrust fault that brings Kueichulin Formation on top of Cholan Formation.

\section{SURFACE FAULT ZONE}

In this section, we report data gathered from shallow boreholes and outcrop studies around the Chi-Chi surface rupture to the west of the TCDP-A drill site. The outcrop and shallow subsurface geology provides additional information for interpreting the equivalent fault systems drilled at TCDP-A.

In this area, the Chi-Chi surface rupture develops near the base of the Cholan Formation (Fig. 5a). Figure 3a shows the stratigraphic column for this area, which was documented from shallow drilling boreholes (i.e., BT11-6, 7, and 8 boreholes) and outcrops. The 50-m deep BT11-7 borehole was drilled and completed one month prior to the Chi-Chi event. This borehole encountered a thrust fault that brings the Pliocene Cholan Formation on top of loose Quaternary terrace gravels that unconformably overlie the Cholan Formation again (Fig. 5c). This thrust fault was later reactivated during the Chi-Chi event, suggesting that the Chi-Chi rupture is reactivated on an old fault plane. Figure $5 \mathrm{c}$ shows that the hangingwall host rocks of this fault zone are gray, fresh sandstones with limited mineral alterations. The fresh fault zone materials in the shallow subsurface suggest that this fault zone is young enough to inhibit strong weathering processes.

Another 30-m deep borehole (BT11-6) drilled some $240 \mathrm{~m}$ to the west of the Chi-Chi surface rupture encountered a previously unknown thrust fault (termed hereafter rupture A, see Figs. 5b, c). Rupture A offsets the unconformity between the terrace gravels and underlying Pliocene strata with a vertical offset of $15 \mathrm{~m}$. Directly above this fault, it consists of about $3-\mathrm{m}$ thick, brown sandstones interpreted as weathering products originating from gray sandstones. Considering that this rupture was not reactivated during the Chi-Chi event and the extent of weathering in the above two fault zones encountered at BT11-6 and BT11-7, respectively, the thrust fault encountered at BT11-6 is likely older than the currently active Chi-Chi rupture. Noting that the Sanyi fault is previously reported as inactive since late Pleistocene (Chen et al. 2003) above observations suggest a hinterlandward (i.e., eastward) migration of splay faults within the thrust-sheet bounding fault zone.

Figure $5 \mathrm{~b}$ shows that the hangingwall strata of Rupture A are gently folded. The anticline is evidenced by west-dipping beds (up to $18^{\circ}$ ) at the footwall outcrops of the Chi-Chi rupture 
as shown in Figs. 5a and $\mathrm{b}$. The westward dipping angle is matched by the bedding dips measured from BT11-6 cores recovered from the west flank of this anticline. The areal extent for this anticline is limited to be less than $1 \mathrm{~km}$ in length along the anticline axis. This type of small anticline is not unique along the length of the Chelungpu fault zone. A similar smallscale, hanging-wall anticline exists in the Chelungpu fault zone about $5 \mathrm{~km}$ south of the TCDP-A well near the Toupienkeng River.

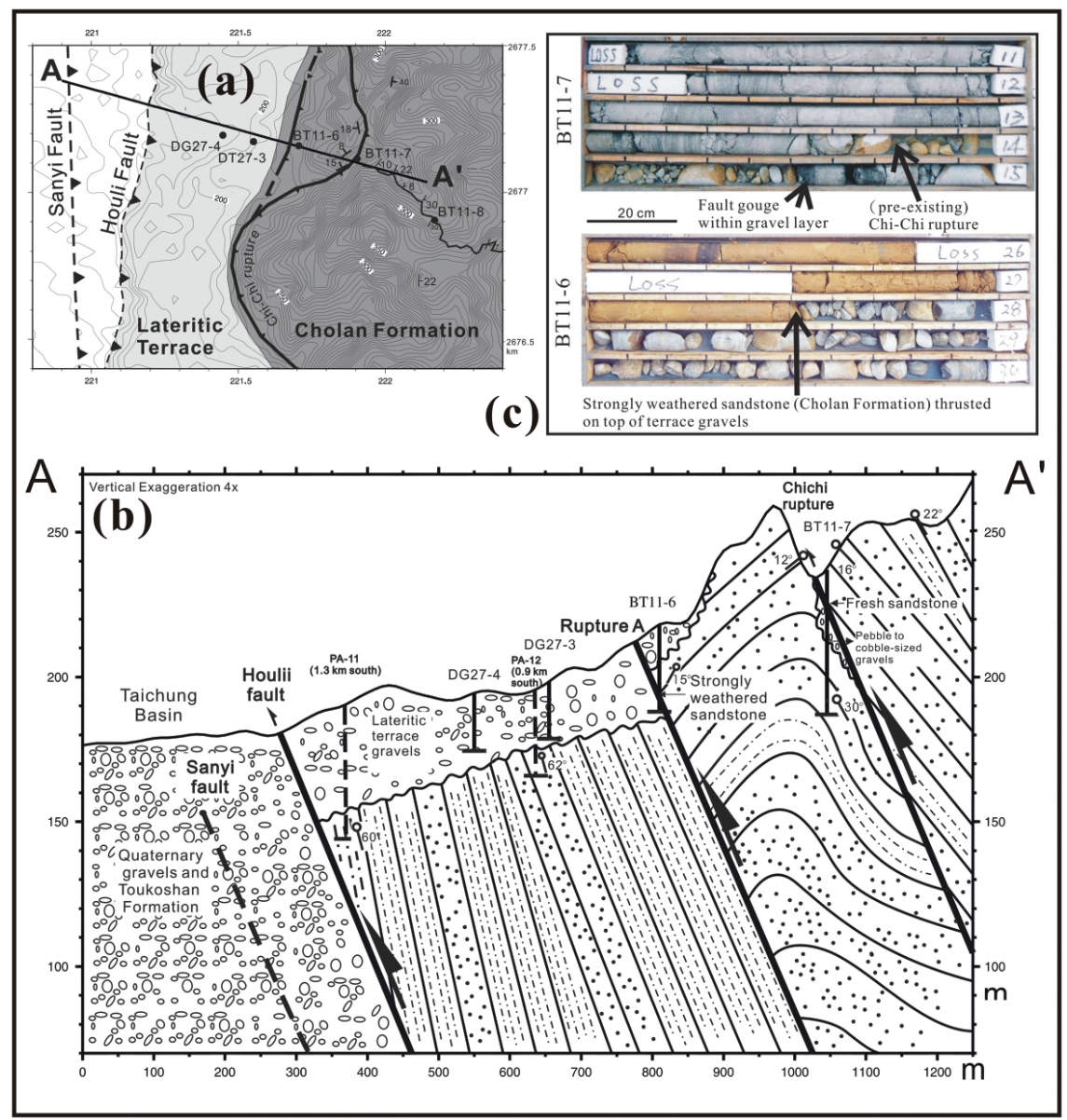

Fig. 5. Shallow subsurface structure of the Sanyi-Chelungpu fault zone to the west of the TCDP-A drill site. (a) shows the geology and the location of AA' profile shown in (b). The faults and their host rocks drilled at BT11-6 and BT11-7 shallow boreholes are shown in (c). The locations of the Sanyi and Houli faults are from Chen et al. (2003). The rock formation that underlies the terrace gravels is undetermined because of limited well penetration. 
Further west of the BT11-6 and to the west of the mountain front, there lies lateritic terrace deposits (Figs. 2, 5). At least two shallow boreholes (PA-11 and 12 shown in Fig. 5b) penetrated through the loose terrace gravels of up to $37 \mathrm{~m}$ in thickness and reached consolidated and steeply dipping (up to $60^{\circ}$ ) shale and sandstone/siltstone beds that unconformably underlie the gravels. The rock formation for the dipping strata lying beneath the terrace gravel is unknown because only limited rock materials were recovered from shallow drilling. According to the correlation of the lithostratigraphic columns between TCDP-A borehole and surface geology as shown in Fig. 3a the formation boundary between the Cholan Formation and the Chinshui Shale may lie somewhere to the west of Rupture A. If this is true we speculate that the rock formation beneath the terrace deposits may belong to the Chinshui Shale.

Figure $5 \mathrm{~b}$ also shows the possible shallow fault structures to the west of the TCDP-A drill site. The interpretation of the Sanyi and Houli faults in the study area shown in Fig 5a follows the thought of Chen et al. (2003). They pointed out that the Sanyi thrust fault is buried beneath the Holocene alluvial deposits of the Taichung Basin as seen from high-resolution seismic reflection profiles shown in Shih et al. (2000). The Houli Fault, a hangingwall branch of the Sanyi fault, runs along the scarp between the terrace and the Taichung Basin according to Chen et al. (2003).

A recent magnetotelluric study (Cheng et al. 2006) that images subsurface resistivity structure down to a depth of $3000 \mathrm{~m}$ successfully delineated the eastward dipping (about $35^{\circ}$ ) Sanyi fault system. From the Sanyi fault in the west and the Chi-Chi rupture in the east, it is an 800-m wide zone of fault disturbance as evidenced by Rupture A that was encountered at BT11-6 and local penetrative shearing zones found at shallow boreholes. The Sanyi fault is a thrust-sheet bounding fault and the Chelungpu fault zone is one of a hangingwall splay fault that may converge with the Sanyi fault at depths.

\section{CONCLUSIONS}

This study reveals that the lithostratigraphy of TCDP-A borehole from top to bottom is as follows: (1) 0 - 1013 m: lower Cholan Formation; (2) 1013 - 1300 m: Chinshui Shale; (3) 1300 - 1707 m: Kueichulin Formation; (4) 1707 - 2003 m: Cholan Formation, a repeated formation in the footwall of the Sanyi Fault.

The Chi-Chi surface rupture occurs near the base of the Cholan Formation while the Chi-Chi rupture encountered at the TCDP-A borehole lies at fault zone $1111 \mathrm{~m}$ within the Chinshui Shale, suggesting that the Chi-Chi rupture cuts stratigraphic upsection of some 170 meters in the direction of faulting transport.

Shallow drilling in and around the Sanyi-Chelungpu fault zone to the west of the TCDP-A drill site reveals a previously unknown and inactive thrust fault lying in between the Sanyi fault in the west and the Chi-Chi rupture in the east. Shallow drilling also shows that the currently active Chi-Chi rupture occurs on a pre-existing fault plane. Noting that the Sanyi fault is previously reported as inactive since late Pleistocene above observations suggest a hinterlandward (i.e., eastward) migration of splay faults within the thrust-sheet bounding fault zone. 
Acknowledgements This research was funded by the National Science Council, Taiwan under the grant of NSC94-2116-M-008-001, with TEC contribution number 00006. We thank the engineers and assistants involved in the Taiwan Chelungpu-fault Drilling Project for their hard work. Comments received from Wen-Shan Chen of the National Taiwan University have greatly improved the quality of this paper. Help from Dong-Jiin Wu and Chyi-Tyi Lee for provision of shallow borehole data is highly appreciated by the authors.

\section{REFERENCES}

Chang, S. S. L., 1971: Subsurface geologic study of the Taichung basin, Taiwan. Petrol. Geol. Taiwan, 8, 21-45.

Chen, M. M., and H. C. Ho, 2000: Correlation between Chi-Chi earthquake ruptures and the Chelungpu fault. Spec. Publ. Cent. Geol. Surv., 12,113-138. (in Chinese)

Chen, W. S., K. D. Ridgeway, C. S. Horng, Y. G. Chen, K. S. Shea, and M. G. Yeh, 2001: Stratigraphic architecture, magnetostratigraphy, and incised-valley systems of the Pliocene-Pleistocene collisional marine foreland basin of Taiwan. Bull. Geol. Soc. Am., 113, 1249-1271.

Chen, W. S., Y. G. Chen, R. C. Shih, T. K. Liu, N. W. Huang, C. C. Lin, S. H. Sung, and K. J. Lee, 2003: Thrust-related river terrace development in relation to the 1999 Chi-Chi earthquake rupture, Western Foothills, central Taiwan. J. Asian Earth Sci., 21, 473480.

Cheng, P. H., A. T. Lin, Y. I. Ger, and K. H. Chen, 2006: Resistivity structures of the Chelungpu fault in the Taichung area, Taiwan. Terr. Atmos. Ocean. Sci., 17, 547-561.

CPC (Chinese Petroleum Corporation), 1982: Geologic map, sheet 4: Taichung, Chinese Petroleum Corporation.

Ho, H. C., and M. M. Chen, 2000: Explanatory text of the geological map of Taiwan, sheet 24: Taichung. Centr. Geol. Surv., Taipei, Taiwan, ROC.

Huang, W. J., Z. Y. Chen, S. Y. Liu, Y. H. Lin, C. W. Lin, and H. C. Chang, 2000: Surface deformation models of the 1999 Chi-Chi earthquake between Tachiachi and Toupienkengchi, central Taiwan. Spec. Publ. Cent. Geol. Surv., 12, 63-87. (in Chinese)

Huang, S. T., J. C. Wu, J. H. Hung, and H. Tanaka, 2002: Studies of sedimentary facies, stratigraphy, and deformation structures of the Chelungpu fault zone on cores from drilled wells in Fengyuan and Nantou, central Taiwan. Terr. Atmos. Ocean. Sci., 13, 253-278.

Hung, J. H., Y. H. Wu, E. C. Yeh, J. C. Wu, and TCDP Scientific Party, 2007: Subsurface structure, physical properties, and fault zone characteristics in the scientific drill holes of Taiwan Chelungpu-fault Drilling Project. Terr. Atmos. Ocean. Sci., 18, 271-293, doi: 10.3319/TAO.2007.18.2.271(TCDP).

Lin, A. T., A. B. Watts, and S. P. Hesselbo, 2003: Cenozoic stratigraphy and subsidence history of the South China Sea margin in the Taiwan region. Basin Res., 15, 453-478.

Lo, W., L. C. Wu, and H. W. Chen, 1999: Explanatory text of the geologic map of Taiwan, sheet 25: Kouhsing, Centr. Geol. Surv., Taipei, Taiwan, ROC. 
Mori, J., H. Ito, and C. Y. Wang, 2002: Chelungpu fault drilling could resolve seismological issues. EOS Trans. AGU, 83, $255 \mathrm{pp}$.

Shih, R. C., S. J. Ho, H. C. Chang, and C. W. Lin, 2000: Preliminary subsurface images of the Chelungpu fault by using shallow seismic reflection. Proc. Inter. Workshop Ann. Commun. Chi-Chi Earthquake, 1, 123-132.

Smith, W. H. F., and P. Wessel, 1990: Gridding with continuous curvature splines in tension. Geophysics, 55, 293-305.

Wang, C. Y., C. L. Lee, and H. Y. Yen, 2002: Mapping the northern portion of the Chelungpu fault, Taiwan by shallow reflection seismics. Geophys. Res. Lett., 29, 951-954.

Wu, J. C., S. T. Huang, M. H. Wang, C. C. Tsai, W. W. Mei, J. H. Hung, T. Y. Lee, K. M. Yang, and K. F. Lee, 2007: Core slabbing and nannofossil analysis on the Chelungpu fault zone, Taichung, Taiwan. Terr. Atmos. Ocean. Sci., 18, 295-325, doi: 10.3319/ TAO.2007.18.2.295(TCDP).

Lin, A. T., S. M. Wang, J. H. Hung, M. S. Wu, and C. S. Liu, 2007: Lithostratigraphy of the Taiwan Chelungpu-fault Drilling Project-A borehole and its neighboring region, central Taiwan. Terr. Atmos. Ocean. Sci., 18, 223-241, doi: 10.3319/TAO.2007.18.2.223 (TCDP). 